\title{
Inventing the Carnival: Contemporary Festivities, Tradition and Imaginaries
}

\author{
Daniela Stavělová - Matěj Kratochvíl
}

DOI: 10.21104/CL.2016.4.03

\begin{abstract}
Since the early 1990s, an increasing number of festivities in the Czech Republic can be observed, constructed after a historical form of the rural carnival ("masopust"). They reveal the needs and intentions of contemporary urban society, which manipulates elements of the carnival in the context of contemporary activities. We focus on the way the structural units of the festivity are selected and appropriated by people within the construction of its contemporary form. The ethnomusicological and ethnochoreological approach enables us to reflect the cognitive process of the participants who makes visible their personal as well as collective experience of the festivity and provides us information about social relationships, culture and collective memory produced together with images of the time. The qualitative field research took place in several districts of Prague and its suburbs, based on relationships between place and interests.
\end{abstract}

Keywords Carnival, festivity, city, tradition, collective memory, music, dance.

This study was written with the institutional support of the Institute of Ethnology of the Czech Academy of Sciences, RVO:68378076.

Contact Doc. Mgr. Daniela Stavělová, CSc., Etnologický ústav AV ČR, v. v. i.,

Na Florenci 1420/3, 11000 Praha 1, Czech Republic; e-mail: stavelova@eu.cas.cz.

Mgr. Matěj Kratochvíl Ph.D., Etnologický ústav AV ČR, v. v. i., Na Florenci 1420/3, 11000 Praha 1, Czech Republic; e-mail: kratochvil@eu.cas.cz.

Jak citovat / How to cite Stavělová, Daniela - Kratochvíl, Matěj. (2016). Inventing the Carnival: Contemporary Festivities, Tradition and Imaginaries. Český lid 103, 569-595. doi:http://dx.doi.org/10.21104/CL.2016.4.03 
The celebration of masopust, the time of carnivals in the Czech lands which historically ended on Ash Wednesday, is without question among the oldest continuous holiday feasts here and, in terms of cultural memory, also the longest transmitted; a festival inextricably linked to contemporary notions of a collective event. One could not fail to notice how since the early 1990s the number of masopust celebrations in the Czech Republic has mushroomed, especially in urban and suburban areas, raising the question of what, in a time of such an unprecedented wide range of cultural activities and diversity of opinion democratizing society, could be the impetus for such a remarkable surge of interest in this phenomenon, still traditionally transmitted and continuously innovated phenomenon. The reality that man is a homo festivans, ${ }^{1}$ as the process of integrating human beings into defined social frameworks of entertainment has concisely and metaphorically been called, as well as the eternal order and submission to authority, many have and will address; however, we will examine why now, where, and for whom the celebration of masopust constitutes an unbroken or rather rediscovered need for social communication. As an historical phenomenon bound for centuries with the existence of traditional societies, this celebration with its ritualized expressions is at the same time a component or reflection of the needs and expectations of today's society, which, with its elements are handled in the context of current events. Our interest is focussed on the selection process of structural units of masopust ${ }^{2}$ festivities and their appropriation when constructing its present forms, steered by the intentions of concrete individuals. An ethnomusicological and ethnochoreological approach allows insight into the cognitive dimension of actors who, through dance and musical repertoire, visualize an image of their own, and hence the collective experience of moments of celebration in opposition to everyday reality. This image also provides information on social ties, and cultural and collective memory, lived in accordance with contemporary imagination. The field for the implementation of qualitative research has become the environment of selected urban and suburban districts of Prague and its surroundings with regard to social cohesion through the awareness of belonging to a place and having common interests. The selection and gradual increase of localities was done through the so-called snowball method, thus expanding the radius of the research field based on gradually forming referential structures. The probe into the process came into being and further profiling of local festivities was observed - open and inclusive, connected with its own

1 Josef Válka (2000) used this notion as the title for his text at the symposium Festivities and Amusements in Courtyards and Towns of the Early Modern Period; for the characteristic medieval townsman, through the year in a series of festivities and getting down to work in short break between the holidays, see Tomáš Borovský (2014). due to its performative elements of interest to both period representations as well as later studies. 
reflexivity and discussions with ordinary participants, but also with the initiators and leading personalities of festivities.

The research has been carried out continuously since 2012, when the Břevnov masopust was first observed, and gradually more locations were added - since 2013, the masopust in Roztoky; and from 2016, those in Prague’s Letná district and in Buštěhrad, near Prague. Given that the research is ongoing, this study will contribute to the definition of the subject of inquiry and serve as an introduction into contemporary studies of the phenomenon by developing its paradigm aided by a variety of approaches of cultural history and socio-cultural anthropology. Through auto-ethnography also examined will be the process of constructing an object of ongoing study for active cooperation of ethnomusicologists and ethnochoreologists within the framework of jointly conducted research.

\section{Phenomenon of masopust celebrations from the perspective of interdisciplinary studies}

Given that masopust or carnival has become a frequent topic of various disciplines, it is worth pausing to look at what approach to the study of the mentioned phenomenon some disciplines take and what their joint benefits can be during the generating of key elements of its structure. It is understandable that for understanding the similarities of contemporary forms of celebration of masopust it is also important to understand the importance of the historical forms of this holiday. The topic of masopust as part of the study of festivals perceives and reflects, in particular, cultural history. Historians in the framework of Medieval Studies have classified masopust into a system of regularly recurring festivals, ceremonies and rituals (Nodl - Šmahel 2014; Borovský 2014), in the historiography of Early Modern history, particular attention has been paid to this in the context of urban culture (Dülmen 2006). As a profane, burlesque and comical feast, arising from the amusement of clerics, it was aptly characterized by the French historian Jacques Heers (2006: 156), who also points out the influence of aristocratic culture in the form of princely tournaments during celebrations of knighthood, wherein he discovered diverse themese such as a travelling ship of fools, oriental elements or Turkish motifs of conquest, grotesque masks with animal heads, etc. According to him, the carnival also ties together burlesque and satirical games, inspired by the shortcomings and failures of society, held by cities or comedic troupes. Carnival in the city thus "became a selection of spectacle provided by the street, but arranged by the aristocracy. Those who can, play, march, dance and sing and hope to push through the crowd to gain recognition.” (Heers 2006: 189) It underscores also the importance of processions associated with people's "need to show off in front of the neighbours, count their numbers, and measure how strong the various bonds of solidarity are. [Carnival] processions are clear and visible 
evidence of the group's the size and cohesion. Processions show numbers and wealth; the processions and games were an opportunity to display wealth, let everyone show their power and social prestige." (ibid .: 141)

Period of celebrating masopust or carnival is also seen (Bakhtin 2007; Burke 2005; Muir 2005) as part of the so-called Culture of Popular Laughter with its grotesque realism and own logic, which features a world of temporary chaos, the reversal of roles and status, as well as food, sex and violence; a sort of upside down world offering a liminal state of being, so as to returned to the solid structure of the social order. The carnival provides an alternative to the normal world, allowing people to organize themselves according to their "own conceptions", underlines the victory of the fool over the wise man, whereas madness is perceived as a stigma, whereby God has marked man, who follows different rules than reasonable people (Heers 2006: 113). This inversion of values celebrates the lunatic and puts him in a prominent place - often as children, because they just are as defenceless and innocent. As an accentuation of masculinity characterizes the English historian Edward Muir (2005: 112), on the contrary, the rituals of violence, i.e. public displays of aggression, which are shrouded in ritual forms of ceremonial matches or sports. These rituals of violence, in the same way regularly repeat annually the "world upside down", offer a soft of sublimation of aggression, disagreement or rebukes to existing social norms and against each other, and are controlled by the venting of couples in fake clashes and duels, through satire, crudity, mutual invective and obscenities mostly permitted within a defined period. It allows however also the ritual slaughter of animals or condemnation and the symbolic execution of a sordid element, cleansing the society of evil, and the smashing or ransacking of old values and establishment of a new and better order. Death is replaced by life, and its pulse gets its own rules again, exactly until the period when the old rules are destroyed and new ones created. The elements of annihilation and purity as replacing the old with the new, the corrupt with the genuine, here have symbolic power, which gives man the strength and hope to survive.

Muir (2005: 101-103) also suggests that the carnival has created a kind of archetypal form, which can be measured also in other kinds of similar celebrations. The components of carnival therefore also can be found in other holidays of the calendar year, for example, in candlelit celebrations, holidays around the erecting of May Poles or the burning of Midsummer bonfires in the form of erotic displays, excess of food and drink, or in the form of madness as a symbol of simplicity and innocence in contrast to depravity. To this, he adds: "Carnival is an opportunity for social gatherings and through ritual vocabulary facilitates the communication of ideas. To understand them, it is necessary to have knowledge of festivities. Ritual language allows you to create a liminal time and space for alternative ideas and space and the possibility to turn the ordinary common values upside down.”(ibid.: 103) 
Elements of violence within the celebration of masopust are perceived by anthropologists as comprising rituals of social protest (Gluckman 1963; Turner, 2004). Expressions of protest against the social order, however, can be interpreted as activities that serve to maintain this order, i.e. the breaking of common taboos and restrictions markedly serve to strengthen them. Whilst these activities may seem to be an open protest against the social order, in reality, they preserve and even strengthen the established order. Max Gluckman (1963: 43) even claims that in situations where social order is subjected to serious criticism, these "rituals of protest" do not occur. Victor Turner (2004: 115) argues that rituals of reversed roles or status provide an "ecstatic experience", a reinforced sense of community followed by a sober return to the normal social structure. "The elevation of the disenfranchised and the humiliation of the powerful confirms the hierarchical principle." This concept brings to the fore the social function of carnival celebrations, whether the participants are aware of it or not.

In Czech ethnological literature, we continuously encounter the theme of masopust from the 19th century on - from the descriptive material contributions, ${ }^{3}$ and through ethnological conceived study, which traces the celebration as part of traditional customs or customary traditions ${ }^{4}$ and of value especially are research findings after World War II, when the number of carnivals celebrated rose especially in rural areas. They note the social functions of customs and their transformations (Tomeš 1977; Frolec - Tomeš 1979), and masopust is sorted into cultural activities, to which apply signs of festiveness, unusualness, and its importance within the common experience, based on mutual interaction, in its effect on the formation of an emotional relationship to the locality entering its history as part of the consciousness of local cultural traditions (Kadeřábková 1991: 49).

The contemporary anthropological view of carnival festivities has moved its study into the area of cultural studies (Karlová 2013), which examines the meaning and significance of these holidays. They base their reasoning on qualitative research data and offer an interpretation of the phenomenon not only within its local connotations but also in the wider theoretical context. They take into account the theme of identity and integration along with issues related to the formation of social status within the framework of the local community (Stavělová 2005; 2006; 2008). Ethnomusicological studies examine the role of music within the cultural patterns of carnival (Kratochvíl - Tyllner 2007).

It therefore may appear that the phenomenon is being adequately worked on from many angles, and that there is no sense in examining it further. Previous work, however, has tended to concern local traditions before modern times which are continuously held, and being innovated or revitalized. In our case, it concerns rather a monitoring of the process of the "invention of 
tradition" in a place where it is not possible to build upon any previous form of celebration. It should be noted that we are studying the category of modern festivities, originating in the intentions of the postmodern society, which in its eclectic approach to the values of the past and present constructs its own reality. When problematising this phenomenon here, we do not find its place in the notion of tradition as a transmission from generation to generation. Neither is it a revival or a representation of some local tradition; on the contrary, it concerns the ad hoc creation of a new situation, which is the result of the fabric of social and cultural ties and need of individuals to find or anchor their experience to their identity within the framework of the wider community. Nevertheless, how it works, or what use it will find in the cultural and collective memory, is a question that challenges us to look further. In other words, we ask how it connects some idea of historical experience and knowledge with the current needs of creation of a modern canon enabling simultaneous interpersonal and social communication. ${ }^{5}$

The negotiation process on the form of contemporary masopust at various studied places is generated from a multitude of recorded interviews and through observation. It could be summarized in advance that the key points of negotiations on the form of the festivities are mainly the following questions:

- Where will the procession go, where does it start and finish, and what has been the relationship to the place where it is held,

- How to involve the public - both adults and children (the emphasis is on families with children) - active participation in the production of masks and their wearing during the festivities,

- How to encourage interactivity through music and dance - what kind of repertoire to choose, when and where,

- Traditional masopust gastronomy conveying historical ties.

Parades, masks, music, dance, and food and drink are indisputably inherent elements of the festivities in all periods; what we are interested in, however, is to find how - with what intentions - today in the proper socio-cultural context are these manifestations manipulated when constructing cultural templates of the celebration called masopust.

\section{The city as a stage, or where processions go $^{6}$}

An important point of departure of our current research is the fact that it is an urban festival. The city space and its concepts from the viewpoint of the theory of urbanism offers many approaches and ideas. The sociologist Zygmunt

6 On the problematization of processions in ethnographic literature, see e.g. Jakubíková 1994. 
Bauman labels urbanized locations as places with a high level of human relations laced with fear, born of a sense of insecurity, that searches for outlets and objects upon which it can lay blame (scapegoats) - although this state has not been forever symptomatic of these places (Bauman 2008: 71). An important framework for exploration therefore will be the distinction because private and public space, whereas public space is perceived primarily as a physical and social phenomenon. According to sociologist William Whyte (2001), public space is a place where people can share their personal lives, share with others, and live as part of a greater whole - the municipality. Richard Sennett (1977) further characterizes public space as a place for the formation of a society based on encounters with diversity. The public sphere here acts as an antithesis to the private sphere - therefore the polarity, which makes a city a city, is linked to concepts of democracy and its formation. This idea was brought to life by the German sociologist and philosopher Jürgen Habermas (1989), who in this context characterized public space as a place above all where one can confront others with their differences, or, conversely, foment the search for commonalities. He conceives of public space especially in connection with the development of democracy and the need for debate on public matters.

The factor necessary to keep in mind today is the uncommonness of public space in modern development and in the nature of modern life, based on the physical and mental mobility of humankind. It stems from the fact that we live at the same time in several places; we are continually drawn into the virtual world beyond physical space and are creating for ourselves an unstable, volatile relationship to place. While previously people were compelled to visit public urban spaces, today it is a matter of choice or preference. Public space therefore often becomes subject to negotiations in accordance with the new forms of its potential exploitation and fulfilment of sense. Thus, public space must be seen as a place where live communication is necessary and people must participate in events in this space; this is the stage for finding a common language (Kratochvíl 2013).

Celebrations of masopust in given districts of Prague and its surroundings happen in public space and therefore logically begin with considerations as to which way processions will lead. As historical experience shows, parades and processions are an inherent part not only of the physical, but especially the social public space, and the visualization thereof. Negotiations on the route of masopust processions are therefore a key issue to be resolved by festival organizers, and not only due to the organized occupation of public areas. Sometimes even the notion of not having to officially apply for this occupation prevails, and the organizers try to draw up a route to take this into account to include other local things, and it becomes rather a communication space. Intentionality of these negotiations regarding the creation of the masopust concept runs up against the intricacies of local constraints and possibilities of the space. 
For the Roztoky masopust there exist two solutions. From the very start, when the celebration's leading figures began to conceive it in 1993, it was considered primarily as an opportunity for processions passing individual households; however, from the outset it was also clear that it would be necessary to proceed in a selective manner.

I moved to Roztoky with my family at the beginning of $1990 s^{7}$ and intended to settle here permanently. Until that time, as an actress I was performing in various groups, I used to the wear shoes of a "stray calf" until the time when I longed to put down roots. Roztoky caught my eye because here I felt the chance to establish deeper relationships, and the masopust tradition offered the possibility for the creative involvement of other people... I tried something similar already where I lived before in Benešov u Prahy. My challenge was, however, that I never actually got any response. Since I myself made a lot of effort about it, so that I started to feel truly at home in Roztoky, I started to think about how to create for local life here some common framework that would enable the active coexistence of local people. So the masopust processions became a way to know people... And to this day that's how it works. Every year we select a certain part of Roztoky for several families who recently have moved here and intend to live here, and they are included in procession routes. They are prepared in advance for how things go and what the rules of the game are. Until now, nobody has refused; everyone tries to be as generous and hospitable as best they can. ${ }^{8}$

This Friday masked procession with music, dancing and refreshments before each selected house has a truly private character. The procession is carried out by a group of people who gradually formed around the theatre company Roztoč focused on street theatre, but has since been joined by other actors who provide the musical accompaniment ${ }^{9}$, or who are involved in making the masks. It originally took place on Saturday, but once the number of participants or rather onlookers began to expand, it became difficult to preserve the character of a home celebration for those who at the same time lived there, and it secretly shifted to Friday, and the procession directed into the community was separated from the flamboyant Saturday costume parade taking

The informant, originally a professional actress, now serves as the founder and head of the "Roztoč" cultural centre in Roztoky. In addition to initiating and organizing many cultural activities, she is involved in local communal life and civic activities. Organizing masopust has become one of her most elaborate activities that seek to promote a relationship to place both for herself and her fellow citizens. 
place in the presence of the mayor and involving the general public. The intimacy of private space for the Friday processions was preserved, with the number of participants clearly defined by who receives and who is accepted, who is a member of the community, and who is ritually incorporated into it.

In addition, the publicized Saturday parade, which passes through historically important places of the village - from the Roztoky chateau continuing through to the flagship commercial plaza to the Holý hilltop, which is situated midway between the municipalities or boroughs of Roztoky, Únětice, Horoměřice and Suchdol, has a different mission. Joining the masked procession, led by an annually changing Queen of Masopust (a local rarity), are several kinds of musical accompaniment in varied random disguises, who are not only Roztoky locals but frequently and repeatedly also visitors from other parts of Prague. The route is secured by blocking the transportation. Acting as the vanguard are the so-called ometačky (sweepers), women who in a dancing motion clear the path on which they lead the procession, also in a visible manner, thereby defining its scope and direction. Apart from the commencement of masopust when the mayor hands over his rights to the main actors, on the podium in front of the Roztoky chateau, another suggestive spectacle is the parade of masks and their raucous introductions on the Roztoky town square in front of the shopping centres, which aims to attract the attention of locals doing their Saturday shopping. The normal operation of the area is completely blocked and everyone, at least for the moment, is preoccupied with this exquisitely staged, raucous spectacle instead of with shopping. All throughout her invocation, controlling and commenting is the main actor (the founder of the local festivities), the emeritus Queen of Masopust. The procession then continues on to the Holý hilltop, where the masked carnival ends - with representatives of the previously mentioned neighbouring municipalities. There will be a comical and grotesquely conceived toothless collision of the "masopust" - sometimes like a dispute between queens, or as bear-baiting display or fight, etc., and then a symbolic reconciliation of everything when the procession ends.

In the evening follows a dance in nearby Únětice that offers in addition traditional cuisine, music and dance activities in the local Sokol pub or the renowned alternative cultural venue known to Praguers as Kravín (the cowshed). To complement local transport there is a special "Masobus" by which participants can easily return to the centre of Prague even late into the night.

It's such a fantastic show, interest is really great, people come from far and wide, and sometimes I feel that already it's too much ... Anyway, we keep for Friday for ourselves - that is ours only, and we prefer it to Saturday, which is more for others, not so much for us already. ${ }^{10}$

10 Interview with Jitka Tichá on 26. 2. 2016. 
While the Friday procession clearly defines private space of the city for local dialogue and its joining with its newest residents, the Saturday procession provides a map of public space that exceeds the framework of one municipality with an awareness of belonging (at least culturally) to a wider area of communal coexistence - Únětice, for example, has a suitable space for a social evening with music and dance, without which the culmination of the Roztoky masopust would not be the same. And conversely, without the creativity, ideas and initiatives of Roztok in organizing the festivities, such a large clientele would not go to Únětice for its gastronomy and local brewery.

Unlike the clear and steady concepts of parades and processions of the Roztoky masopust, for the one at Prague's Letná, the question of routes for the procession remains under negotiation. The Letná masopust has been held for only three years, and the first two were more of a coming together of a handful of people affiliated with the manager and owner of the Scarabeus gallery and café (in the street also dubbed in the past as "Letná's Montmartre") to the Prague masopust, held on the Old Town Square. It was only this year that it began to be conceived as a local celebration and preparations began to receive special attention. The event has the support of local councilors - the mayor in the guise of Bacchus not only gives a humorous speech to pass his rights into the hands of the masopust actors, but also engages in other events. Paramount, of course, has become the question of which way the procession will proceed. Two options were considered: 1. to lead the procession from a gathering on Strossmayer Square outside the Church of St. Anthony after the Milada Horáková high street on to Letná Park, across from Scarabeus with a stop for treats and a short performance by jugglers and dancers, with the end of the procession at the National Museum of Agriculture, which also takes part in ensuring the festivities, especially by conferring space for refreshments and the subsequent cultural programme. Or 2 . in case a large number of people do not pass along the busy main avenue but go around the Trade Fairgrounds Palace through Stromovka and Letná. Although eventually the first option won out, the very next day after the festivities an intense debate began on what would be better still in terms of opportunities for more intensive, active involvement of people. This year's parade showed little organic connection with the normal operation of the street, and onlookers were missing, so the procession on the main commercial street went almost unnoticed. Traffic did not have to be diverted because the parade did not exceed the number that would fit on the pavement, and although police on horseback were ensuring safety when crossing the road, their very presence assured appropriate publicity, and the procession led by the band through a quite indifferent street, which was not drawn into the entertainment and had no opportunity to react to any stimuli. Apparently lacking was character who would be unmistakable, provocative, create a stir and drum up interest in the area. In the future, therefore, under consideration are ways to involve small business owners and 
shops along the high street but also a second option, which also counts on the suggestions of the National Gallery in the Trade Fairgrounds Palace, which would contribute to a cultural programme, and a stop there could be conceived as part of the procession with a welcome "home". The subsequent approach through Stromovka again could offer a stop at places with an opportunity for outdoor space for dancing. The question however remains whether this would bring the procession outside of the radius of the quarter and thereby lose contact with its internal pulse.

The parade of Břevnov masopust, which has been held regularly since 1994, has had a clear objective from the start. Because it is organized by the Břevnov association of entrepreneurs, its path leads clearly along the main thoroughfare of Bělohorská Avenue and enjoys the heavy representation of local tradesmen. The route is not long and runs from the historically significant house U Kaštanu past Hotel Pyramid, in front of which the procession ends with the announcement and awaring of the best masks, and music and dancing and gastronomy from ceremonial appropriate hogkillings. For many years at the head of the procession there has been a butcher who represents one of the most significant family businesses to be reformed in Břevnov immediately after 1989. An essential element of this procession is the character of orator (a "plampač") equipped with a megaphone who throughout draws attention to specific companies and their establishments along Bělohorská Avenue, making witty comments. In several places, it will also stop for a small treat (at a bakery, a butcher's shop), with the masked participants laying siege to these small shops and thus encouraging their operators to come out and greet the masopust. The procession is quite interactive, with many witty comments addressed directly, people are constantly joining in, or look out of windows. Vehicular traffic is redirected from the main roads in both directions, although trams run as usual on the tracks, and participants are constantly alerted by police to look out for their safety. The atmosphere here is friendly; many people greet each other.

The Buštěhrad masopust parade has a similar atmosphere, characterized by a procession led by musicians that stops at selected stores. The route runs across rugged villages, starting at the museum native of writer Ota Pavel, a native son, and ending at the oldest local pub in the village. Treats at the visited homes are rich, with their residents trying to outdo each other in presentations of traditional masopust gastronomy.

\section{Becoming an insider is rather easy}

The key prerequisite for participating in these celebrations is wearing a mask, which is generally perceived as an important step to show one's affiliation to the annually featured masopust community. In Roztoky, even visitors have the opportunity before the procession on Saturday to buy a simple mask, or 
to rent one from the Roztoč culture association which can be returned after the parade in Únětice at specially furnished cars. In addition, there is a remarkable amount of creativity among participants, who year after year provide a colourful spectacle. The focus and core in Roztoky of the Saturday parade, however, has for many years been specific masked participants, who over the years have taken shape under the name Chudadlo, apparently from the stilts on which these oversized figures with elongated arms move. Operating the stilts already requires adequate skill but privilege of wearing them belongs to a narrower circle of direct participants associated with the Roztoč association. Similarly, it is possible to classify the mischievous monkey who each year come up with new acrobatic stunts, climbing on trees and buildings, or nudge other participants in the parade. The Roztocky masked participants are already so familiar in appearance, they have become identified with the place. However, they can be found also in the Brrevnov masopust, which people from Roztoky helped to get running and still today proceed there, for a fee, to help guarantee that it has the true carnival spirit. Aside from the creativity displayed in creating masks, some also play the traditional village masopust figures - bears and their trainers, old hags with baskets, or sprightly goats.

Great care is devoted to the mask also during the preparation of the Letná masopust. Its initiator and organizer, Kateřina Ebelová, ${ }^{11}$ hasn’t denied her artistic and theatrical education and profession of gallerist and offers a variety of opportunities to ponder the origin and significance of the mask right at the source. In the Scarabeus gallery, for example, this year during the time of masopust she arranged an exhibition of masks by contemporary artists, which she herself commissed under the theme of masks in our lives. In the week before the celebration of masopust in Letná, in her gallery she organized several workshops for the public to provide material and inspiration for creating a mask, arising mainly from one's own imagination.

I'll be there ready, even if no one comes. I would like to offer people space to think about everything a mask can offer. To learn how to work with them and make the most of the possibilities inherent in one's own metamorphosis in a mask. To discover the world under a mask; to see themselves through the masks that you create for yourself. ${ }^{12}$

11 The informant has a lively, a warm relationship to the place where her grandparents worked, and where she runs a gallery and lives with her large family. Her gallery and related to Museum of Coffee with a café has become a significant part of local cultural life; it hosts events for children and their parents, systematically reshaping and extending outdoor areas in adjacent gardens in multifunctional spaces where families with children, actors, small theatre forms, street theater performers can meet, along with figures in local municipal politics. She examined question of issues with masks in her dissertation (Ebelová 2012). 
The Břevnov masopust, in contrast, abandons the initiative to manufacture masks for each individual, whilst trying to motivate participants to take this step by announcing and rewarding winners in a competition for the best mask. The themes are completely open, and creativity has no limits, so the masopust parade in this urban area, which thanks to the involvement of the local nursery school is focussed on child participants, results in an unusual number of fairytale creatures, which only contemporary children brought up on television stories can, with the help of their parents dream up. Here is assembled a special group that continually observe masks and at the end of the parade evaluate which are the best. Those are then announced and awarded by a representative of the local municipality; in recent years, the deputy mayor of the city. During the parade, however, the participants are continually encouraged by the "plampače" to become more involved in masking process; in years when participation is plentiful and varied masks are evaluated approvingly, however, these are in a reproachful tone.

As a way of participation and active involvement, disguising onself with a mask is an important part of the Buštěhrad masopust processions. Children and adults of all generations take part, and their creations are here entirely left to the imagination of each person or interest groups.

\section{Musical community and its own world}

As the masopust procession must not only be seen but also heard, involving different types of musical production is one of the primary tasks of ensuring the conquest of public space. This is ensured by the participation of various types of bands that play at explicit stages of the parade, during the procession or at a dance. This thereby creates a specific circle of lay musicians who are repeatedly included in the carnival actions connecting and generating within the framework of their own musical world a distinctive repertoire. ${ }^{13}$

The relationship between music and the place where the music is present has, over the course of the past two decades or so, garnered more frequent attention from ethnomusicologists. Researchs of course registered the bond between music and the specific locality far earlier, but only gradually coming into view are the possible variants of this relationship beyond a statement that a given song was written in a particular place. It is shown that a place as not only a physical but also a mental space can influence musical activity, but on the contrary, they are also influenced, or even formed, writes Thomas Solomon: "That musical performance is a practice for constructing identity is now an ethnomusicological commonplace. That it can also be a practice for constructing place may not seem so obvious at first. Geographers and anthropologists working on the cultural construction of place have recently

13 See Jurková 2014. 
explored how places are not simply backdrops for activity, but rather are actively made and imagined by people through social processes." (Solomon 2006: 311) At the masopust in Roztoky u Prahy, for example, within the framework of such a limited spectrum and through the construction of a musical repertoire it is possible to see it from a variety of perspectives. We are interested mainly in this Friday, closed part. The main question is how repertoire (i.e. what is played) combined with performance (i.e. how is it played) creates a new unit from seemingly disparate elements.

Musical accompaniment of the Roztoky masopust processions are not the same each year, and their appearance is likewise always changing. The following text is based primarily on research conducted in January 2016, and on interviews with actors and materials provided to me. To illustrate the research situation, it is necessary to add that this concerned participant observation. Participants in the processions agreed with the researcher's presence only on the condition that, as a musician, a clarinetist with experience of folk music, he would also play during the procession. This perspective, of course, influenced the information gathered during the observation, because it enabled contact during the tour mainly with musicians and it was not, for example, possible to assess that well how the dancers perceived the music, and other people moving farther away from the musicians. On the other hand, it was possible to closely observe the communication between musicians. The following sections offer a concise description of the events taking place on Friday, from about four o'clock in the afternoon until midnight.

The band comprised a violin, two violas, a contra bass, clarinet, flute, accordion and drums. The violinist, violists and flutist have experience from playing in a folklore group. The drummer, one violist, flutist, bassist and accordionist are locals, whilst others live elsewhere in Prague. Among the musicians was also one masked participant with a trumpet, which, in her own words, she learned how to play just a few months. Her performance is also quite simple, and after some time ends. As part of the procession of masks, the musicians also before the start don masks and dress in costumes. In comparison with other masked participants in the procession, the musicians were only partially disguised so as not to hinder their playing.

The band (with no drummer, and with a second accordionist who during the last procession in the end didn't play) a week prior to the procession together practised a core repertoire. An important tool was a songbook containing the core repertoire for both components of the tour: caroling at homes and in the transitions between them. The songbook originated many years before the current musicians began to engage in the procession. According to the musicians, the compilation of the songbook began about a decade ago, drawing on various sources. The participants had this songbook, containing twenty songs, in printed form; however, it was clearly not intended for public disseminati- 
on. ${ }^{14}$ The songbook includes various kinds of songs from different regions of Bohemia, Moravia and Slovakia. In addition to folk songs without a known author, we find the song Podzim (Autumn) by Petr Skoumal with lyrics by Emanuel Frynta; with new verses added with a masopust theme. During the 2016 procession, this song, as well as many others from the song book, was not performed; conversely, many songs not listed in it were.

The songs have no special arrangements; mostly, they alternate between sung verses and instrumental parts. The exception is the song Jsom já synek $z$ Orešan (I am a son from Orešany), where the violins play a short rhythmic introduction as a transition before some verses, as was agreed during practice. All the musicians sing as do most of the masks. The band has no official leader or frontman. The decisions on what they will play, in what tempo and key, stem from different initiatives by individual musicians. The accordionist is at the same time something of a conductor or director of the procession, and at times he decides on his own to block the passage of a car and play in front of it until the entire procession passes, which some drivers accept less well than others. The distribution of roles among instruments corresponds for example to Moravian string bands, in which violins play the main voice, and the viola acts as a "kontry", i.e. plays in double stops to create a harmonic and rhythmic accompaniment; the flute and clarinet play alternately the first and second voices. The accordion at times is limited to the harmonic accompaniment, and at times also plays a melody.

After starting the procession, the band goes quite a while before arriving at the first house where they should stop. The transitions between other stops are relatively long, and over time the pauses between songs become longer. Weather plays a big role, which this evening is quite chilly, which also influences the music. Temperature of a few degrees below freezing affects the temperment of instruments, which become out of tune, a complication which the musicians do not even attempt to resolve. Some instruments as a result are consequently changing from melodic-harmonic to purely rhythmic. The violist plays wearing thick mittens, which excludes the possibility of precise play on the fingerboard, and the case of the contrabass player was similar. Inside the clarinet, after about two hours, a layer of ice begins to form and the instrument simply refuses to hit the notes. During the procession, the musicians sometimes proceed in a single group, whilst at other times they disperse quite far from one another, during which time they continue to play. The beat of the drum acts as an audible bond from afar, and helps to synchronize the other instruments. The exception is a few songs with variable beats, during which the drummer ceases to orientate himself and the rhythm disintegrates.

When playing in front of houses the band is situated near the Queen of Masopust, so that the accompaniment to the core procession songs is properly

14 At the time of the research, the organizers were considering a publication intended for the public. 
heard. They play outdoors with the exception of at penultimate home, when the entire procession is invited inside to warm themselves. In the living room, they then play and dance for about thirty minutes. Apart from the aforementioned blocking of cars, they come into more intensive contact with the public whilst heading to the final household. All participants in the procession along with the band pack themselves into a local city bus with its somewhat startled but otherwise friendly driver. The atmosphere in the crowded vehicle inspires all to more intense playing and singing. At the final household, the mode of the music changes. At this point, the closing ceremony of the procession takes place, which takes the form of freewheeling music and dancing. Another violinist and a cymbalist playing on a small portable cimbalom join the band.

The masopust festival, in all of its forms, includes food and drink - especially alcohol. So it is with the Roztoky procession, where apart from refreshments prepared for individual stops along the way, musicians carry a small bottle of slivovice (plum brandy), which circulates among them. Nevertheles the influence on the the musicians of consuming alcohol throughout the entire evening does not become too apparent.

The songs which the musicians have chosen for the masopust procession come from various localities in the Czech Republic. What strategy can we find behind their choices? And how can we understand this hybrid repertoire within the context of the coming into being of a "new tradition"?

Music plays several roles during masopust processions: it serves as an accompaniment to dancing and for transitions between individual households creates an audible space framing the procession and separating it symbolically from the surrounding area. The repertoire is divided into two groups. The first part is closely coordinated with the dancing, delivery of speeches and other activities that take place at various stops. Also in this part it is possible to observe some flexibility and variability, but the basic components are always present. The second part of the repertoire covers transitions of groups of carollers between the individual houses. Given that the carollers were invited by only a few families as regards Roztoky, these stops comprised a substantial part of the evening, during which they did not dance and so the selection of songs was solely up to the musicians.

The first group includes songs associated with specific dance manifestations: the melody of the song Šla Židovka do Slanýho (A Jewess Went to Slaný) which accompanies dancing in the street, we find in the so-called Rittersberg collection of Czech folk songs published in 1825 (Markl 1987: 247), which specifies its occurrence in Pilsen and Chrudim. The song Za ten len, za ten len, za ty konopičky, for example, is in a collection of folk songs from Havličkủv Brod (Thořová 2009: 183). Its structure is different form other songs when the sung melody alternates with all participants jumping. Before the jumps, the music creates an amplified acoustic prepare gradually tremolo on one chord, followed by a jump and repetiton of the melody. These two songs are the most 
stable core repertoire and are firmly in place. Other activities taking place at various stops, especially dances with guests, are less fixed and are accompanied by different melodies.

During the transitions, the musicians chose songs from a relatively wide range, but some songs were repeated more often than others. Among these songs are Poslechněte lidé málo, co se v české zemi stalo (Plicka - Volf 1960), Zadělala na buchty (Markl 1987: 342), Pane bratřiččku, dobrej den (Erben 1862), Já si tě má milá nevezmu (Erben 1862: 551), Když jsem já šel po mezi (Holas 1909: 126), and Jsom já synek z Orešan (Sušil 1859: 544). It is difficult to find much of a connection between the songs as regards both the music and lyrics. In some cases, they have a connection to masopust, whlist in others, they are just humorous or drinking songs. The lyrics of the central Šla Židovka do Slanýho have nothing to do with masopust, but can be understood as a reference to the mask of a Jew, which is oftern part of the masopust procession.

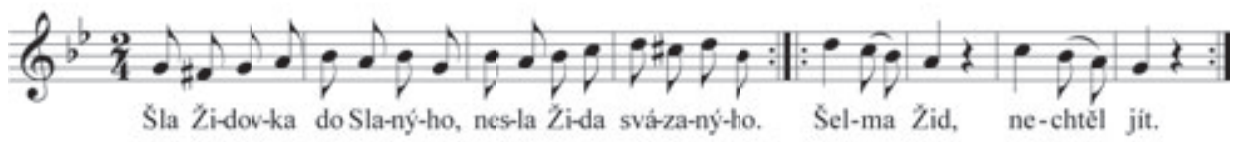

The same can be said of the theme of the song Byli jednou tři Židi (Thořová - Traxler - Vejvoda 2011:228). At other times a selection of songs driven by efforts to emphasize the character of masopust as a time when normal rules do not apply and the social order gives way to chaos, as characterized by Michail Bachtin (2007). The text is therefore ripe with nonsensical humor, drunkenness and gluttony. Especially popular during the procession is a ditty which musicians sing in a theatrically exaggerated "drunken expression" with an accordingly irregular rhythm:

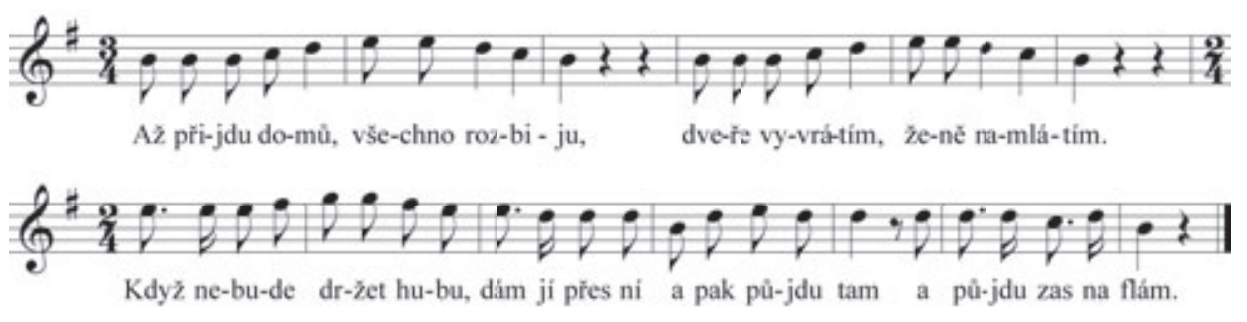

(see also Thořová - Traxler - Vejvoda 2011: 223)

Whilst it is possible to trace where the songs were collected, it is not possible to clearly identify how they became part of the masopust repertoire. Many of them the musicians probably knew from their time in folk music groups. Others apparently came from a targeted search through published collections. But of course the question of the origin is not considered important by the musicians. This was confirmed also during the aforementioned preliminary practice sessions, when 
each musician from the memory pitched melodies that could possibly expand the repertoire. Nobody cared about the origin of the song at that moment.

\section{Tradition versus fusion}

In the realm of traditionally perceived European folk songs culture, songs are always perceived as formations closely linked to their place of its origin. The identification of songs as units native to concrete locations featured in the 19th and 20th centuries an important part of collecting, researching and publishing activities. At the same time, collectors very early on began taking into account the fact that such tying to a specific site is however limited, and songs can conversely be regarded as "the most tireless tourists on earth" (Tappert 1890: 5). Regional purity is therefore to a certain extent illusory, because the repertoire and style of individual areas has always been in flux, and regions influence each other. Nonetheless, it concerns quality, which within the folklore movement has always been frequently underscored. When looking at existing collections of folk songs from the Czech Republic, it is clear that various regions have enjoyed greater attention from collectors and therefore a larger repertoire is often associated with them than with others. Some areas have remained almost untouched by collectors.

Roztoky u Prahy is one such virtually untouched locality. ${ }^{15}$ In the search of a repertoire for the emerging local festivities, their actors therefore decided to go the way of hybridization, linked unrelated material together into a new whole. The unifying element has - besides some of the themes mentioned above - become the style of play. Hybridization can take various forms, including the deliberate linking of distinctly different musical positions and styles, as can be heard in the case of groups combining folk music with rock and electronic instrumentation. Within the public parade through the city the following day is connected a musical production involving several bodies, at first encounter, one also hears a distinct style and the hybridity is underscored as an important quality. ${ }^{16}$ During the Friday processions it is of course the musical variety on the first hearing, morphed into a homogeneous form.

Most of the musicians who took part in this procession have significant experience in a folk group and find themselves in a somewhat contradictory situation. The ensemble in which they play focusses on one region of southern Moravia and, like a number of similar bodies, stresses a certain regional purity.

15 This also applies generally to folk songs from Prague and its surroundings, where only in recent years have the gaps been filled, thanks to the gradual publishing of collections of František Homolka from the early 20th century (Thořová - Traxler - Vejvoda 2011; 2013). Previously released volumes contain more than one song each from Únětice and Šárka, a site adjacent to Roztoky; however, neither song is in the Roztoky masopust repertoire. 
This is reflected in the selection of songs and the way they are performed. Emphasis on a local or regional identity of music can be understood as an effort to combat cultural homogenization. This concern is nothing new, nor is it limited to the Czech and Moravian folk movement (see e.g. Nettl 1983: 345). At the same time, however, it threatens to transform traditional music into the museum setting, and also conceals the fact that no rigorously fixed form truly exists, and thus creates a false image (Kratochvil 2013). A certain degree of unification is sustainable when seen in historical sources, and on specific occasions, such as with annual customs, a certain degree of limitation in choice has always been evident. An example could be the recently examined masopust procession in Dobrkovská Lhotka (Kratochvíl - Tyllner 2007) which lasts all day, and the accompaniment consists of an accordion, trumpet and bass flugelhorn, which consistently turn out only three songs.

Authenticity, in traditional music, is mostly understood among other things as respect for the original locality repertoire and the approach of the musicians from Roztoky is in apparent contradiction to this notion. Here it is of course necessary to recognize that different understandings of authenticity exist. In the masopust of Roztoky, we find a different situation than did collectors in the 19th century such as Erben or Sušil, who still could perceive songs as firmly tied to a locality when writing. More than a hundred years later, thanks to the development of technology, the movement of populations from rural to urban areas and other factors, the confinement of songs to the sites where they were recorded is markedly weaker. The very notion of authenticity in music also was often problematized and redefined (see e.g. Connel - Gibson, 2003: 19-45). Ties between music, places and communities of people are always being re-defined through concrete performance. Instead, in this case, ties have become not only physical (because not all participants live in Roztoky) but also a symbolic or mental. Music therefore becomes a force that adds another dimension to a place defined physically or geographically. As in Roztoky, the musical accompaniment is organized by local musicians -also part of the experience of from ensemble movements - for example, in Buštěhrad, another locality not overly captured in collections of folk songs. In contrast, for example, the Žižkov masopust uses professional musicians with no concrete connection to the place.

\section{Space for dance}

Negotiations on the form of dance are also key in the creation of similar celebrations of masopust in all the areas mentioned. In every cases concerned, the climax of the masopust celebration is considered to be the shared amusement through music, dancing and a tombola, a moment, therefore, bringing people a bit closer to one another. Even here, however, this process does not proceed in the same way. The basic question is what to dance. The Břevnov masopust 
organizers wriggled out of this question rather well. Already for many years, as part of the event, procession participants are invited to the Hotel Pyramid, where there is a masked ball. The theme of masks (e.g. music, food, from fairy tale to film) as a sort of dress code varies each year. It is already next to impossible to arrive at this soiree in civilian clothes, or without at least wearing a mask. Without such a disguise one soon begins to feel out of place, and markedly, like someone who does not belong here. It seems that amongst themselves, participants often know each other as members of local trade associations, though any new face embellished mask is accepted as a matter of course. A hired band plays at the dance which is adept at playing a varied repertoire of swing, foxtrot, blues, polka or waltz tunes, including favourite disco hits. The dances with some urgency is attended by most of the participants without respect to age - even if the foxtrot and polka are not for everyone, here it matters not: anything goes in a mask. And so the dance floor fills up for spontaneous creations of whatever kind of music, as well as for the carefully choreographed spinning of the noble waltz.

Entertainment in the Únětice pub (Sokol) takes on a similar character after the Roztoky masopust procession. Here the "rocky" actors meet in so-called Dolnopovltavský kroj (regional folk costume), which they design and make themselves using their female part, with anyone who feels like staying here after finishing the parade even in touristic clothing. The dance floor is always full. The experienced dance band settles on stage to play an endless repertoire of dance tunes. Gliding around on the floor in a tango rythmn is a couple of refined figures from the Prague Milonga; beside them, sporting a backpack and a with glass of beer in hand, is a lonely young man; a bit farther away is group of gleeful girls showing off improvised creations of an undetermined theme, many are swaying on a spot tuned away from the place from where the music emanates, drinking and feeling just as free as if at a rock concert. The dance here for everyone means that they dance as they know how to, and so can contribute to the atmosphere of the dance floor.

The situation is however different for the Friday processions in Roztoky. Here, dance has a different mission than just to foster a feeling of belonging and sharing in a relaxed atmosphere. It is important here to bring into communal events those "unknown" who have moved here. Dancing together here becomes a shared value, which must be defined and set off from the common vocabulary, and from it a ritual language created that those who should understand it learn. Towards this is compiled a specific repertoire of of purely masopust songs and dances, engaged only in this context. They were sought in the collections of folk songs and dances and implemented with the specific intent of involving the target group of actors consisting of participants in the procession and new residents. In from of each visited home danced a Jewish woman - a very simple set of dances with the gradual involvement of couples into a common dance. Performing these individual simple steps requires no special 
knowledge of dance, it's just important for the couple to understand when they should bow whilst facing each other and when back to back. This simple form allows for a rapid connection to the dance for all involved. Later, they play more challenging pieces - such as the dance with changing meter - the bear (Já si tě, má milá, nevezmu, že ty jsi podobná medvědu - "You, my dear, I will never marry, for you resemble a bear"). None of the participants know that the dance alternates two and three measures, but even so still dance in as a pair with carollers who in an improbable manner take to the dance. Nobody is unwilling, dancing with masks means that it is all for fun and not about the dance. The collective dance of the procession participants with the "housholders" ends with a so-called jumping into the flax (Za ten len, za ten len, za ty konopičky "For this flax, for this flax, for the linnen"), all at the right moment along with the lyrics, together they all jump high, and the dancing at that moment mingles with the voice of the Queen of Masopust, who on behalf of them all wishes the homeowners lots of love, children and happiness in their new home. Originally a folk dance with elements of prosperity magic (however high they jump whilst dancing, that's how high the flax will grow) can even today be an expression of wishes for success and abundance. They repeat this ceremony of "welcoming the new citizens" before each selected household.

\section{I chose the dances based not only on how they were connected} to masopust as such, but that at the same time they were simple so people could jump in quickly. This taking part in the dances is like a welcome among us. There are still still few dances, however. People don't know what to dance, that's why I decided to hold on a regular basis dance classes in the Roztoky courtyards - always somewhere else, in a private space, depending on who will be willing that afternoon to hold the event in their courtyard. We will invite lecturers here who will teach the folk dances from different regions, so that people are better prepated and able to dance a much wider repertoire than before. ${ }^{17}$

In Buštěhrad they offer something rather different, with dances held in an interesting and stylishly designed wine cellar. It promises to be an exceptional experience, judging by posters promoting dulcimer band called Buštěhradištan of Ota Pavlica - a verbal pun composed from the name of the municipality and the name of a well known proffessional music band Hradištan led by Jiří Pavlica melted with the name of the writer Ota Pavel, native of Buštěhrad. The repertoire of Moravian folk songs and dances stirs the blood in our veins, but the dance floor remains empty. Only later did one couple attempt their

17 Interview with Jitka Tichá on 26. 2. 2016. That same year, in the spring, the first Roztoky courtyard session teaching Moravian dances was held, accompanied by dulcimer music compiled ad hoc by members of various folk music ensembles. 
own version of the csárdás, which soon gets out of hand (or foot), and the weary pair head back to their table. The relaxed mood is lifted at last by the announcement of an imaginative tombola with recycled prizes, which amuses the staff. After that, the fun started to revolve more around individual tables and their consumption. People here know each other quite well, however, so the convergence of dance is not so needed. The fun, however, rather soon comes to an end and they slowly part ways.

And who are you? - a lady at the next table asked me. Will you write about us in the newpaper? - she continued, looking at my photographic equipment. Not at all, I reassured her, so that she didn't think that I'm some paparazzi who trails the tabloid press, I'm just ethnologist and masopust interests me... Ah, she continued, clearly delighted with my interest, so you could help us by contributing photos to our newspaper. You know, this year, our photographer didn't show up, and we want to record our masopust every year. Pictures of dancing we generally are missing - and yet people here are having so much fun. We have tried a variety of cultural activities so that we feel like among are close ones, so people will want to come back and will feel at home here. We've been having a masopust since 2005 and there's always something that can be improved... ${ }^{18}$

The big nut to crack is how to use the possibilities of dances to actively involve people in the festivities, which became an issue for the organizers of the Letná masopust. Its spectacular nature has ensured dances at the dance department of the local Elementary School of the Arts. In front of the church on the square, children performed a stylized form of masopust figure marching to the music of Hradištan at the closing of festivities and then at the National Museum of Agriculture a so-called Balfolk dance class was held. Accompanied by Balkan folk music, and there was a spontaneous tuition in the the readily defined dance style with the aim of involving participants. Word of this item on the agenda, however, came at the late hour, and only a handful of people took part. The organizers were therefore scratching their heads about how to resolve the issue of dances and how to get space and time for them in the coming years. Dance is seen as an important means of interaction, without which masopust would not be as it should. It's just about what dance will bring people closer, how people even get to the dance, in which part of the festivities it will be most suitable, and so what space will be provide an appropriate environment. Some local halls with sufficient capacity often do not attract those interested in dance to visit and, conversely, where local like to go there is not enough space for dancing. Under consideration also is to create the position of an "animator", 
who also during the parade would show an natural, unforced way to induce an atmosphere for dancing, and to quickly teach them the moves.

The last two examples demonstate a lack of dancing skills on the basis of which it is possible to utilize the performative elements of dance, which help to develop intensive local spaces for communication. It then happens on the level of symbolic communication, which is transmitted to people to share common emotions. Organizers of local festivities are aware of these options for dances and therefore are looking for a way to resolve the situation in a world of fragmented interests and different cultural experiences.

\section{Between cultural memory, imagination and collective identity of imagined community}

What unites all these given cases of masopust celebrations is the fact that they represent a search for the expression of a contemporary need for a socialable coexistence. This occurs when it involve the use of elements of rural forms of masopust from premodern times to construct a cultural template for modern festivities. Selected, however, are not only those elements which resonate with conception of values, ideas, creativity, fantasy or political and civic attitudes, which can be collectively shared. In accordance with such imagination go hand in hand efforts to create a kind of common canonized form of mutual existence, which could be regularly repeated and fulfill other areas. This brings up the question of why now masopust. A significant moment is its historically indisputable inclusion in time, even though the date of the celebration is today often set in different locations according to local needs (e.g. due to spring holidays) and displaced from up to two or three weeks and Ash Wednesday need not always be the definitive ending of masopust. But that does not change the fact that the celebration of masopust is mostly associated with the period around the original end; in the annual cycle, it has a solid footing and has become one of the few immutable certainties. A weighty reason for the contemporary celebration of masopust here certainly can be without question a sort of historical experience with its conceptualisation, which allows the manipulation of meanings in the spirit of common intentions. Significant factors can be that the process of representation of the village masopust in an urban environment can proceed in a great variety of ways and at different levels of cultural memory, which here easily become a collective - some first encountered masopust long ago in the countryside at his grandmother's home, some experienced it in the neighboring district, saw it on television or read about it somewhere, etc. Collective memory, according to Maurice Halbwachs (1992: 54), forms a conscious relationship to the past; memory takes shape from the images of absent things. The brain updates these things in the form of images and adapts them to specific situations. Memory, however, is at the same time socially conditioned, and in the process of reminiscing enters only that which 
is related to the present. The repetition of memories creates a tradition which Halbwachs defined as a reconstruction of memories in a definite convention. Jan Assmann (2001: 36-38) adds that the collective memory governs behavior and the recollection in the framework of interactions within society and to some extent simplifies these processes by presenting collectively shared examples. Essential is that collective memory only works with the narrow selection of historical facts, adapting its images, and is used for various purposes. In cultural memory, the past is moulded into symbolic figures which are present in the ceremonies that have a festive character, whereby these figures of memories found a group identity. For collective memory, social environment is important - a person here identifies with the events, personalities, etc., but their duration is limited to the duration of this group. ${ }^{19}$

Finally, it also offers a reflection on which elements of contemporary Prague masopust constitute and which are lacking when compared to its historical forms. A surprising finding is at first sight the obvious absence of conflict, legitimized violence and satire. It invites comparison with the current research of Basel Fasnacht, which is the largest carnival in Switzerland and at the same time a "fountain of creativity, satire and freedom" (Cieslarová 2011: 13). Built upon a historically documented local tradition, it is also a phenomenon of contemporary society balancing creatively through artistic representation with current local and general hot topic, which are with impunity, fully and exaggeratedly displayed and expressed (Meier - Christ 1968). It is a manifestation of a mature democratic society with a strong sense of collective identity that is informed about what is going on around them and reacts in an enlightenbed manner with direct force, which lends the freedom of masks and the liminality of carnival days. Satire and pamphlets are carefully prepared long in advance and ignore nothing of note. This holiday has functioned as an instrument for social dialogue, perhaps since the its very inception. In contrast, the predominant characteristic of the Prague masopust festival is an effort to reach consensus, and the space for liminality is used rather as an alternative to thought. The possibility of the presence of conflict and the so-called rituals of violence (Creed 2004: 56-70) perhaps incited fears of these becoming a reality (Le Roy Ladurie 2001). Only rather gingerly this year for the first time appeared in the Břevnov parade banners with a sigh: "Many fools, few clowns." It is therefore possible that gradually also satirical aspects are taking hold and a way will be found to manipulate and use them as a language of public space.

Although this "construction of tradition" largely corresponds to the concept of "invented tradition" (Hobsbawm - Ranger 1983), the question arises as to wheter it really will become a tradition. A basic attribute of tradition, namely a transmission from generation to generation, requires always several generations with a strong bond to the place in order to guarantee the continuity of 
transmission. Although in contemporary festivities children are consistently involved and it is sometimes possible to get the impression that it is held especially for them and their parents, it is impossible in today's mobile world to expect that they will remain in the environment once they come of age. In constructing a cultural template, however, there is a possibility for its regular annual repetition in a given time, and such repetitiveness creates consciousness of the ritual, which always starts again to feel like a sort of a collective identity. This construct also becomes the intellectual property or kind of symbolic capital (Bourdieux 1993) of the thereby defined community, with which at its regular renewal participates in and identifies. The community that arose from it at the same time is imaginary because it arises and exists mainly in the minds of people, whilst its consistency with the place is often uncertain and changeable (Anderson 1991; Boyes 1993). This process can therefore be rather characterized as inventing and shaping the community, which can exist only as long and often as its current actors make an effort, and for which it becomes an alternative way to achieve a sense of collective identity in the boundless space urbanized areas.

\section{September 2016}

\section{References}

Anderson, Benedict. 1991. Immagined Communities: Reflection on the Origin and Spread of Nationalism. New York: Verso.

Assmann, Jan. 2001. Kultura a pamět. Písmo, vzpomínka a politická identita $v$ rozvinutých kulturách starověku. Praha: Prostor.

Bachtin, Michail. 2007. Francois Rabelais a lidová kultura středověku a renesance. Praha: Argo.

Bauman, Zygmunt. 2008. Tekuté časy. Praha: Academia.

Borovský, Tomáš. 2014. Svátky a slavnosti středověkého města. In: Nodl, Martin - Šmahel, František (eds.): Slavnosti, ceremonie a rituály v pozdním středověku. Praha: Argo.

Bourdieux, Pierre. 1993. The Field of Cultural Production. Cambridge: Polity Press.

Boyes, Georgina. 1993. The Imagined Village. Culture, Ideology and the English Folk Revival. Manchester and New York: Manchester University Press. Buckland, Theresa. 1995. Embodying the Past in the Present: Dance and Ritual.
In: Dabrowska, Grazyna - Bielawski, Ludvik (eds.): Dance, Ritual and Music. 18th Symposium of the ICTM Study Group on Ethnochoreology, Skierniewice, 1994, Poland. Warsaw: Polish Society for Ethnomusicology, Institute of Art, Polish Academy of Sciences.

Buckland, Theresa. 2001. Dance, Authenticity and Cultural Memory: The Politics of Embodiment. In: Kaeppler, Adrienne L. - Christensen, Dieter - Wild, Stephen (eds.): Yearbook for Traditional Music 33: 1-16.

Burke, Peter. 2005. Lidová kultura v raně novověké Evropě. Praha: Argo.

Cieslarová, Olga V. 2011. Fasnacht. V Basileji karneval? Praha: Brkola, s. r. o.

Cohen, Anthony P. 1985. The Symbolic Construction of Community. London: Routledge.

Connel, John - Gibson, Chris. 2003. Sound Tracks: Popular Music Identity and Place. London: Routledge.

Creed, Gerald W. 2004. Constituted through Conflict: Images of Community 
(and nation) in Bulgarian Rural Ritual. American Anthropologist 106: 56-70.

Dülmen, Richard van. 2006. Kultura a každodenní život v raném novověku (16.-18. století). Díl II. Praha: Argo.

Ebelová, Kateřina. 2012. Maska v proměnách času a kultur. Praha: Grada.

Erben, Karel Jaromír. 1862: Nápěvy prostonárodních písní českých. Praha: Nákladem vydavatelovým.

Frolec, Václav - Tomeš, Josef (eds.). 1979. Masopustní tradice. Lidová kultura a současnost sv. 5. Brno: Blok.

Frolec, Václav. 1982. Lidová obyčejová tradice a obřadní kultura.

Terminologické otázky. Národopisné aktuality 19: 253-272.

Frolec, Václav. 1984. Prostá krása. Deset kapitol o lidové kultuře v Čechách a na Moravě. Praha: Vyšehrad.

Gluckman, Max. 1963. Order and Rebellion in Tribal Africa. Collective essays with authobiographical introduction. London: Cohen and West.

Habermas, Jürgen. 1989. The Structural Transformation of the Public Sphere. An Inquiry into a Category of Bourgeois Society. Cambridge, MA: MIT Press. [German 1962]

Halbwachs, Maurice. 1992. On Collective Memory (Heritage of Sociology). Chicago; London: University of Chicago Press.

Heers, Jacques. 2006. Svátky bláznů a karnevaly. Praha: Argo.

Hlubuček, Jan. 1953. Doudlebský rok. II. Zvyky masopustní. Trhové Sviny: Doudlebský archiv národopisný: nepublikovaný materiál, fond EÚ AV ČR, v. v. i.

Hobsbawm, Eric - Ranger, Terence (eds.). 1983. The invention of Tradition. Cambridge: Cambridge University Press.

Holas, Čeněk. 1908-1910: České národní písně a tance. Díl I-VI. Praha: B. Kočí.

Jakubíková, Kornélia. 1994. Sprievod ako etnologický problém. In: Tarcalová, Ludmila (ed.): Slavnostní průvody. Uherské Hradiště: Slovácké muzeum: 17-22.

Jurková, Zuzana a kol. 2014: Pražské hudební světy. Praha: Karolinum.

Kadeřábková, Jaroslava. 1991. Slavení masopustu a vesnická lokální společnost.
(Některé výsledky současného srovnávacího výzkumu v ČR a SRN). In: Jančář, Josef (ed.): Slavnosti v moderní společnosti. Sborník př́spěvků z XI. Strážnického sympozia, 11.-12. 9. 1990. Strážnice: Ústav lidové kultury: 44-50. Karlová, Jana. 2013. Slavnosti a rituály jako zpráva o obrazu světa. Červený Kostelec: Pavel Mervart.

Kratochvíl. Petr. 2013. Architektura a veřejný prostor. Praha: České učení technické.

Kratochvíl, Matěj. 2013. Už zase zachraňují národní tradice. [201610-10] Retrieved from: http://www. hisvoice.cz/cz/articles/detail/1600.

Kratochvíl, Matěj - Tyllner, Lubomír. 2007. Masopustní koleda na Doudlebsku. Praha: Etnologický ústav AV ČR.

Le Roy Ladurie, Emmanuel. 2001. Masopust $\checkmark$ Romansu. Od Hromnic po Popeleční středu 1579-1580. Le Carnaval de Romans. De la Chandeleur au mercredi des Cendres 1579-1580. Praha: Argo.

Markl, Jaroslav. 1987. Nejstarší sbírky českých lidových písní. Praha: Editio Supraphon.

Meier, Eugen A. - Crist, Robert B. 1968. Fasnacht in Basel. Basel: Pharos - Verlag.

Muir, Edward. 2005. Ritual in Early Modern Europe. Second edition. Cambridge: Cambridge University Press.

Nettl, Bruno. 1983. The Study of Ethnomusicology. Twenty-nine Issue and Concepts. Chicago: University of Illinois Press.

Nodl, Martin - Šmahel, František (eds.). 2014. Slavnosti, ceremonie a rituály v pozdním středověku. Praha: Argo.

Plicka, Karel - Volf, František. 1960. Český rok v pohádkách, písních, hrách a tancích, říkadlech a hádankách. Zima. Praha: Státní nakladatelství krásné literatury, hudby a umění. Sennett, Richard. 1977. The Fall of Public Man. New York: Knopf.

Solomon, Thomas. 2006. Dueling Landscapes, Singing Places and Identities in Highland Bolivia. In: Post, Jennifer C. (ed.): Ethnomusicology, A Contemporary Reader. London: Routledge: 311-328. 
Stavělová, Daniela. 2005. The Dancing Poeple - Status, Identity, Integrity. In: Dunin, E. I. - Wharton, A. von Bibra - Felföldi, L. (eds.): Dance end Society. Dancer as a cultural performer. Budapest: Akadémiai Kiadó, European Folklore Institute.

Stavělová, Daniela. 2006. Doudlebská masopustní koleda: tanec jako text. Národopisná revue 16: 28-37.

Stavělová, Daniela. 2008. Červená růžičko, proč se nerozvijišs. Doudlebská masopustní koleda: tanec, identita, status a integrace. Multimediální studie. Praha: Etnologický ústav AV ČR, v. v. i.

Sušil, František. 1859: Moravské národní písně s nápěvy do textu vřaděnými. Brno: K. Winiker.

Šubrt, Jiří - Pfeiferová, Štěpánka. 2010. Kolektivní pamět jako předmět historicko-sociologického bádání. Historická sociologie 1: 9-29.

Tappert, Wilhelm. 1890. Wandernde Melodien. Leipzig: List \& Francke.

Thořová, Věra. 2009: Lidové písně z Havlíčkobrodska, Havlíčkův Brod: Muzeum Vysočiny.

Thořová, Věra - Traxler, Jiří - Vejvoda Zdeněk. 2011. Lidové písně z Prahy ve sbírce Františka Homolky. Díl I. Praha: Etnologický ústav AV ČR, v. v. i.

Thořová, Věra - Traxler, Jiří - Vejvoda Zdeněk. 2013. Lidové písně z Prahy ve sbírce Františka Homolky. Díl II. Praha: Etnologický ústav AV ČR, v. v. i.

Tomeš, Josef. 1977. Společenská funkce lidových obřadů a obyčejů a její změny v životě současných generací. In: Premeny ludových tradícií v súčasnosti. Československo. Veda: Bratislava: 127-135.

Turner, Victor W. 2004. Průběh rituálu. Struktura a antistruktura. The Ritual Process: Structure and Anti-Structure by Victor Turner. Computer Press: Brno.

Válka, Josef. 2000. Homo festivans. In: Bůžek, Václav - Král, Pavel (eds.): Slavnosti a zábavy na dvorech a rezidenčních městech raného novověku. Opera historica 8: 5-19.

Vančík, František. 1969. Kalendářní obyčeje z jihočeského Soběnova. Masopust. Opera Ethnologica 4. Praha: ÚEF ČSAV.

Whyte, Wiliam H. 2001. The Social Life of Small Urban Spaces. New York: Project of Public Spaces.

Zíbrt, Čeněk. 2006. Veselé chvíle v životě lidu českého. Praha: Vyšehrad. 